Fountain Journal of Natural and Applied Sciences: 2015; 4(1): 27 - 34

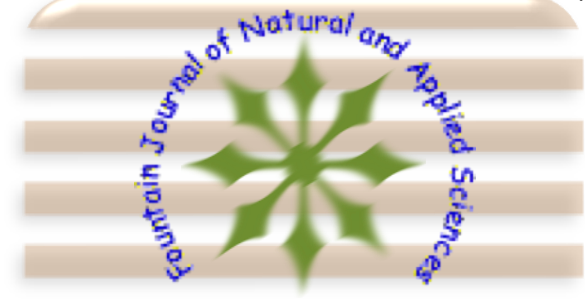

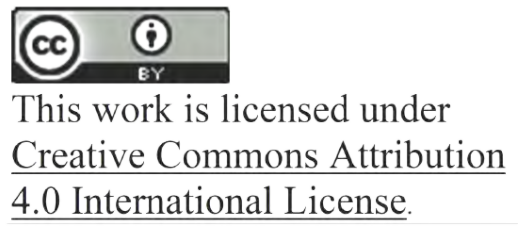

DOI: 10.53704/fujnas.v4i1.53

A publication of College of Natural and Applied Sciences, Fountain University, Osogbo, Nigeria

Journal homepage: www.fountainjournals.com

ISSN: 2354-337X (Online), 2350-1863 (Print)

\title{
Effects of Purified Jatropha curcas Seed Oil-Based Diet on Growth Performance and Hematological Parameters of Albino Rats
}

\author{
Maiyaki-Musa, A. ${ }^{1}$ and Muhammad, N. O. ${ }^{2}$ \\ ${ }^{1}$ Department of Biological Science, College of Natural Science, Al-Hikmah University, Ilorin, P. M. B. 1601, Kwara State, Nigeria, \\ ${ }^{2}$ Department of Biochemistry and Molecular Biology, Faculty of Science and Technology, Federal University Dutsin-Ma, P. M. B. \\ 5001, Katsina State, Nigeria.
}

\begin{abstract}
The effect of inclusion of Jatropha curcas seed oil, as a source of oil in the feed of animal, on growth performance, hematological parameters and histology was investigated. Feed intake, average body weight gain and mortality were also monitored. Milled Jatropha curcas seeds were subjected to oil extraction using batch method. Hematological parameters were determined using standard operating procedures. Twenty weanling albino rats with mean weights ranging from $41.57 \pm 7.90 \mathrm{~g}$, were divided into two groups. The first group was placed on soybean oil-based (control) diet ( $4 \%$ oil) while the second group was placed on Jatropha curcas seed oil-based diet (4\% oil), for four weeks. There was a significant higher difference $(P<0.05)$ in the growth performance of rats fed the control diet when compared with the test group. The animals placed on the control diet showed significantly higher $(P<0.05)$ body weight when compared with the test diet during the last week of experimentation and this might be due to the low digestibility of the Jatropha curcas seed oil-based diet. The result also shows a higher percentage mortality in the group fed the test diet when compared with those fed the control diet. Hematological parameters did not differ significantly $(P>0.05)$ in both the control and test diets respectively but a significantly higher difference in neutrophils of those fed the control diet when compared with those fed test diet. This may signify that continuous ingestion of Jatropha curcas seed oil may reduce the body's immunity against infections. The histological assessment of liver, kidney, heart and small intestine revealed no visible lesion. Overall, the result showed that Jatropha curcas seed oil has the potential of been a source of oil in animal diet if complete detoxification can be achieved.
\end{abstract}

Keywords: Jatropha curcas seed oil, growth performance, lipid digestibility, antinutrients, phorbol ester.

\section{Introduction}

The main source of oil in animal feed is soybean oil which is usually under heavy consumption by human. Thus, there is need for search of other sources, which can be found in tropical plant seeds with promising nutritional

*Corresponding author: +2348182774648

Email address: bintamayaki@hotmail.com 
value which can be used to replace the competed soy oil.

Although, there exist antinutrients in these tropical plant seeds oil which not only render their nutrients unavailable but could also be toxic to the cells of the animals, sometimes leading to their death (Butler, 1989; Butler, 1992: Muhammad and Oloyede, 2004:, Muhammad et al., 2004 and Muhammad and Oloyede, 2010). Reports have shown that these antinutrients may also leads to dehydration, sunken eyes, skin irritation, loss of appetite, loss of condition and finally death (Belewu et al., 2008), increased faecal mucus production and food rejection (Makkar et al., 1998). Among such tropical plant seeds that have been reported to be rich in oil is the seed of Jatropha curcas (Achten et al., 2007 and Achten 2008).

Jatropha curcas L. or physic nut is a species of flowering plant in the spurge family, Euphorbiaceae that is native to the American tropics, most likely Mexico and Central America (Janick and Robert, 2008). Jatropha curcas oil is a by-product of Jatropha curcas seed after oil extraction. It is available in large quantities (Achten et al., 2007) and is a viscous oil which contains very little other components and has a good quality for burning. Cetane number of $J$. curcas oil (23-41) is close to cotton seed (35-40) and better than rape seed (30-36), groundnut (30-41) and sunflower (29-37) (Vaitilingom and Leinnard, 1997). The toxicity of $J$. curcas is mainly because of phorbol esters and curcains. Due to its toxicity, $J$. curcas oil is not edible and is traditionally used for manufacturing soap and medicinal applications. Although the oil has a high energy content, other components of this plant may also be used as an energy source (Gübitz et al., 1999 and Augustus et al., 2002). The fatty acid composition of Jatropha curcas seed oil (Carraretto et al., 2004) consists of myristic, palmitic, stearic, arachidic, oleic and linoleic acids. Arachidic and linoleic fatty acids are essential fatty acids that help in the production of signaling molecules that mediate the inflammatory response. They also function as permeability barrier and has important role in cell structure.

This feature distinguishes Jatropha curcas seed oil from soybean oil. Soybean oil that is readily available in the country is hydrogenated, as soybean oil is too unstable to be used in food manufacturing. Among the problems with partially hydrogenated soybean oil is trans fat and the health hazards of the soy itself, as well as the prevalence of genetically engineered soybeans today. Soybean oil is commonly used to make mayonnaise, salad dressing, margarine, and nondairy coffee creamers. It is a usual feature of processed foods, which is where the problem begins: processed foods are perhaps the most dangerous part of most people's diet, contributing to the occurrence of cardiovascular disease and poor health. The main focus of this work is to see how well purified Jatropha curcas seed oil can be well tolerated by rats in terms of growth performance.

\section{Materials and Methods \\ Chemicals and reagents}

The chemicals and reagents used were of analytical grade and were gotten from Sunaf Nigeria Limited, behind Glo world, off Taiwo Road, Ilorin, Kwara State, Nigeria.

\section{Source and Processing of Jatropha curcas Seed Ripe Jatropha curcas seeds were} purchased at Emir's market in Ilorin metropolis, Kwara State, Nigeria. The seeds were de-husked and de-hulled manually to gain access to a creamcolored endocarp. The sample materials were oven dried at $60^{\circ} \mathrm{C}$ and blended to powder form with a high-speed blender. The dried, milled Jatropha curcas seed was subjected to oil extraction using petroleum ether by batch method to remove excess oil present and the oil was used to formulate (as an open-formular diet) diets given to the animals during the period of experimentation.

Vitamins/mineral mix was sourced from AFFCOM feeds, Sango Ilorin, Kwara State. The composition is as shown below table 1. 
Fountain Journal of Natural and Applied Sciences: 2015; 4(1): 27 - 34

Table 1: Percentage Composition of Diet $(\mathrm{g} / 100 \mathrm{~g})$

\begin{tabular}{ccc}
\hline Ingredients & Control meal & Jatropha curcas seed oil meal \\
\hline Corn starch & 51.6 & 51.6 \\
Soymeal & 25.0 & 25.0 \\
Soy oil & 4.0 & -- \\
Cellulose & 4.0 & 4.0 \\
Sucrose & 10.0 & 10.0 \\
DL-Methionine & 0.4 & 0.4 \\
Jatropha curcas seed oil & -- & 4.0 \\
*Vitamin/ Mineral mix & 5.0 & 5.0 \\
Total & 100 & 100 \\
\hline
\end{tabular}

-- Not available

*Vitamin/ Mineral mix: Vitamin A, 15,000,000 iu; Vitamin $D_{3}, 4,400,000$ iu; Vitamin E, 1,350mg: Vitamin K, 4,350mg: Vitamin $B_{2}, 4,350 \mathrm{mg}$ : Vitamin $B_{6}, 2.350 \mathrm{mg}$ : Vitamin $B_{12}, 11,350 \mathrm{mg}$ : Vitamin C, 1000mg; Nicotinic acid, 16,700mg: Panthotenic acid, 5,350mg; Potassium chloride, 87,000mg: Sodium sulphate, 212,000mg; Sodium chloride, 50,000mg: Magnesium sulphate, 12,000mg; Manganese sulphate, 12, 000mg; Copper sulphate, 12,000mg: Zinc sulphate, 12,000mg; Lysine, 15,000 mg; Methionine, 10,000mg.

\section{Animals}

Twenty weanling albino rats with weights ranging from $41.57 \pm 7.90 \mathrm{~g}$, were randomly allocated into two treatment groups. The rats were kept in a laboratory environment and allowed to acclimatize to the environment for a week, fasted overnight and then placed on the formulated diets (Table 1) for four weeks. Group feeding was carried out and the animals were supplied feed and water ad-libitum.

Daily feed was supplied to the animals and the left over was weighed. At the end of the week, the feed consumed per week by the animals was obtained by difference and divided by the number of animals within each group to obtain the feed intake per animal in each group. Average daily feed intake was obtained for each group by dividing the total amount of feeds consumed within the specified period by number of animals in the group.

The number of animals that died over the period of experimentation was noted and percentage mortality was calculated.

Digestibility study was carried out during the last week of the experiment. The animals were kent in metabolic canes made of slatted floor covered with fine wire netting that allows the passage of urine while the faeces were collected in the tray under the cage. Total faeces voided by individual animal were weighed daily and was dried at $60^{\circ} \mathrm{C}$ for $24 \mathrm{hr}$ for lipid determination.

\section{Hematological Parameters Determination}

Hematological parameters were determined using standard operating procedures (Dacie and Lewis, 2006). This was done at the expiration of the feeding period. The animals were sacrificed and blood samples were collected in hematological bottles containing anti-clotting agent (EDTA) to prevent clotting. The parameters analyzed includes; packed cell volume (PCV), total white blood cell (TWBC), white blood differential, neutrophils, lymphocytes, monocytes, eosinophils and basophils.

\section{Histopathological Assessment of the Tissues}

At the expiration of the feeding period, the animals were sacrificed. Heart, liver, kidney and small intestine of the rats were removed, cleaned free of blood and fixed in 10\% Buffered Neutral Formalin (BNF) solution at $25^{\circ} \mathrm{C}$ 


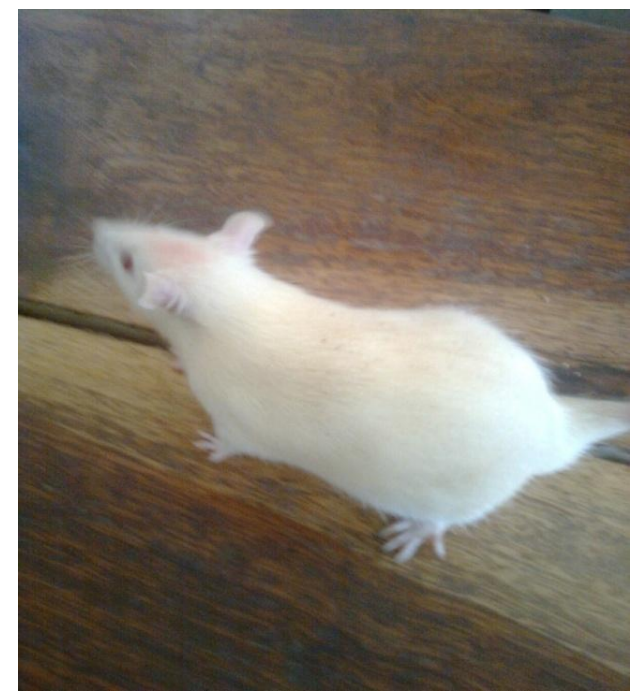

Figure 1: Physical appearance of rats fed on control diet

Histological study on the tissues was carried out following the procedure described by Drury and Wellington (1973). Fixed tissues were dehydrated through ascending grades of ethanol (50\%, 60\%, $75 \%, 80 \%$ and $90 \%$ ). They were then cleared in xylene, impregnated and embedded in paraffin wax (melting point $50^{\circ} \mathrm{C}$ ) and were cut on a rotary microtome. The cut sections were floated out on clean slides which had previously been lightly coated with egg albumin preparation to avoid detachment from slides during staining procedure. The sections were dried for $2 \mathrm{hrs}$ at $37^{\circ} \mathrm{C}$, dewaxed through xylene and dehydrated through

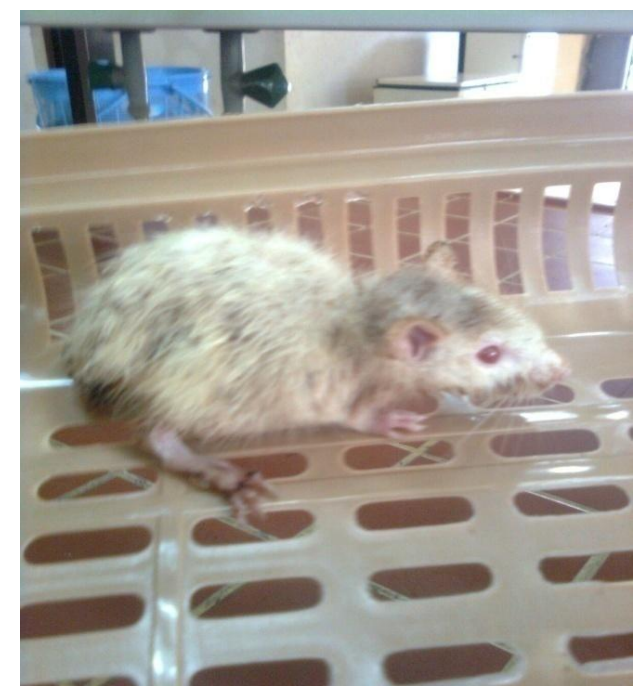

Figure 2: Physical appearance of rats fed on Jatropha curcas seed oil-based diet.

descending grades of ethanol to water. They were then stained in alcoholic eosin, mounted on Canada basalm and labeled appropriately. The slides were then viewed under Leitz, DIALUX Research Microscope and the photographs were taken in bright field at $\times 400$ magnification.

Data were expressed as the mean \pm standard deviation (SD). Statistical difference between groups were assessed by independentsamples T-test using SPSS version 16.0 (Statistical program for Social Sciences) and $p$ values $<0.05$ were considered significant.

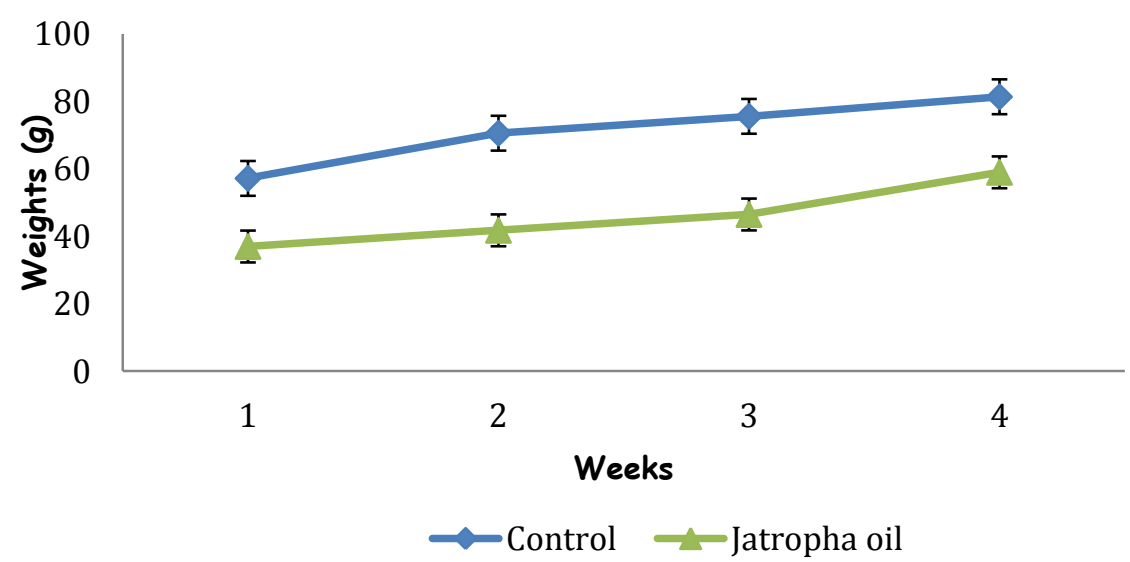

Figure 3: Growth response of experimental animals fed control and Jatropha curcas seed oil-based diets. 


\section{Results}

\section{Growth Performance}

The physical appearances of rats fed control diet and Jatropha curcas seed oil-based diets are shown in Figures 1 and 2. There were significant differences in the morphology of the rats. Those fed the control diet were normal, had smooth hairs and agile throughout the experimental period while those fed Jatropha curcas seed oilbased diet reveal stunted growth, having sunken eyes, loss of hair and scaly legs.

Figure 3 shows the growth rate curve of rats fed the control and Jatropha curcas seed oilbased diets. There were significant reduction $(P<0.05)$ in the average feed intake of the animals fed Jatropha curcas seed oil-based diet when compared with the control. Also, high percentage mortality was recorded in rats fed Jatropha curcas seed oil-based diet when compared with the control as shown in Table 2.

Table 2: Food intake and growth rate of rats fed Jatropha curcas seed oil diet.

\begin{tabular}{ccc}
\hline Parameters/Diets $(g)$ & Control & Jatropha curcas seed oil \\
\hline Initial weight & $41.60 \pm 8.11^{\mathrm{a}}$ & $41.50 \pm 5.57^{\mathrm{a}}$ \\
Final weight & $81.40 \pm 12.64^{\mathrm{a}}$ & $48.00 \pm 15.56^{\mathrm{b}}$ \\
Daily food intake & $8.10 \pm 0.84^{\mathrm{a}}$ & $3.90 \pm 1.31^{\mathrm{b}}$ \\
Daily weight gain & $2.91 \pm 0.45^{\mathrm{a}}$ & $1.72 \pm 0.56^{\mathrm{b}}$ \\
Body weight gain & $3.98 \pm 1.38^{\mathrm{a}}$ & $0.20 \pm 0.85^{\mathrm{b}}$ \\
$\%$ Mortality & - & 80
\end{tabular}

All values are means of seven determinations \pm SEM. Means with different superscripts are significantly different from the control at $(P<0.05)$.

Table 3: Changes on organ body weight ratio of selected tissues of rats fed Jatropha curcas seed oil based-diet.

\begin{tabular}{ccc}
\hline Organs & Control & Jatropha curcas seed oil \\
\hline Liver & $0.05 \pm 0.02^{a}$ & $0.05 \pm 0.00^{a}$ \\
Heart & $0.00 \pm 0.00^{a}$ & $0.01 \pm 0.00^{a}$ \\
kidney & $0.01 \pm 0.00^{a}$ & $0.01 \pm 0.00^{a}$ \\
\hline
\end{tabular}

All values are means of five determinations \pm SEM. Means with different superscripts are significantly different from the control $(P<0.05)$.

Table 4: Hematological parameters of experimental animals fed Jatropha curcas seed oil based-diet.

\begin{tabular}{ccc}
\hline Parameters/ Samples & Control & Jatropha curcas seed oil \\
\hline PCV $(\%)$ & $38.30 \pm 1.13^{a}$ & $39.50 \pm 0.50^{a}$ \\
Conc of $\mathrm{Hb}(\mathrm{g} / \mathrm{dl})$ & $12.77 \pm 0.38^{a}$ & $12.84 \pm 0.23^{a}$ \\
TWBC (No of cell $\left.\times 10^{9} / \mathrm{L}\right)$ & $4.87 \pm 0.16^{a}$ & $4.45 \pm 0.15^{a}$ \\
Differential White Blood Cells $(\%)$ & & \\
Neutrophils & $57.40 \pm 0.72^{a}$ & $50.50 \pm 0.50^{b}$ \\
Lymphocytes & $36.70 \pm 0.42^{a}$ & $35.00 \pm 1.00^{a}$ \\
Monocytes & $5.50 \pm 0.64^{a}$ & $7.50 \pm 0.50^{a}$ \\
Eosinophils & $1.50 \pm 0.22^{a}$ & $2.00 \pm 0.00^{a}$ \\
Basophils & - & -
\end{tabular}

All values are means of five determinations \pm SEM. Means with different superscripts are significantly different from the control at $(P<0.05)$ 
Table 3 shows the organ body weight ratio of rats fed control and Jatropha curcas seed oil-based diets. The result also shows a high percentage lipid digestibility of the control diet than the Jatropha curcas seed oil-based diet.

\section{Hematological Analysis}

Table 4 shows the hematological parameters of the whole blood of experimental animals placed on control and Jatropha curcas seed oil-based diets and it shows no significant difference $(P<0.05)$ between the two groups except for neutrophils which were significantly lower $(P<0.05)$ in Jatropha curcas seed oil-based diet.

\section{Histological Assessment}

The results of the histopathological assessment of the tissues of rats fed the control diet and Jatropha curcas seed oil-based diet for four weeks are shown in plates 1-8. The photomicrographs showed that the cells of the heart, liver, kidney and small intestine of rats fed Jatropha curcas seed oil-based diet appear normal when compared with those of the control diet.

\section{Discussion}

The significant increase in the body weight (Figures 1 and 2) of rats fed control diet over the Jatropha curcas seed oil-based diet might be due to the phorbol esters present in the Jatropha curcas seed oil which leads to rejection of food by the animals and this might be due to change in taste or odour of the feed. All the animals in the control group appeared normal and well nourished throughout the period of feeding which is due to the better utilization of the nutrients present in the diet when compared to the Jatropha curcas seed oil fed group which appeared malnourished after the second week of feeding. Also, there were loss of appetite, loss of hair, sunken eyes, scaly legs and tail, skin irritation, which corresponds to the symptoms of phorbol ester toxicity and these includes dehydration, sunken eyes, skin irritation, loss of appetite, loss of condition and finally death (Belewu, 2008), increased faecal mucus production
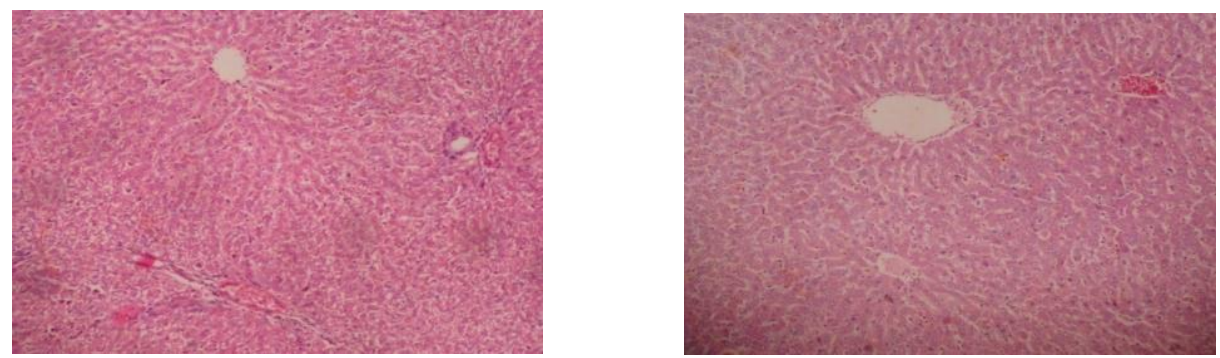

Plates 1 and 2: Photomicrograph of the liver of rats fed the control and Jatropha curcas seed oil-based diet for four weeks ( $H$ and $E \times 400)$. There was no visible change in the architecture of the liver of animals fed the test diet compared to the control diet.
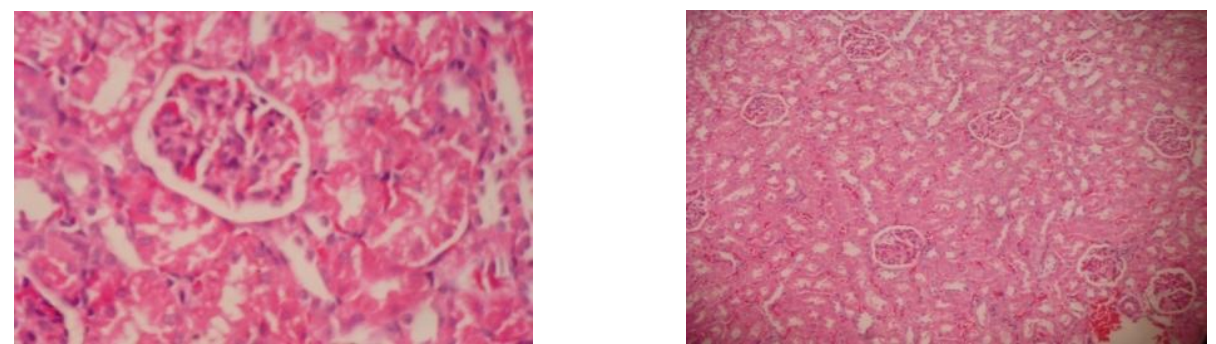

Plates 3 and 4: Photomicrograph of the kidney of rats fed the control and Jatropha curcas seed oil-based diet for four weeks (H and $E \times 400)$. There was no visible change in the architecture of the kidney of animals fed the test diet compared to the control diet. 

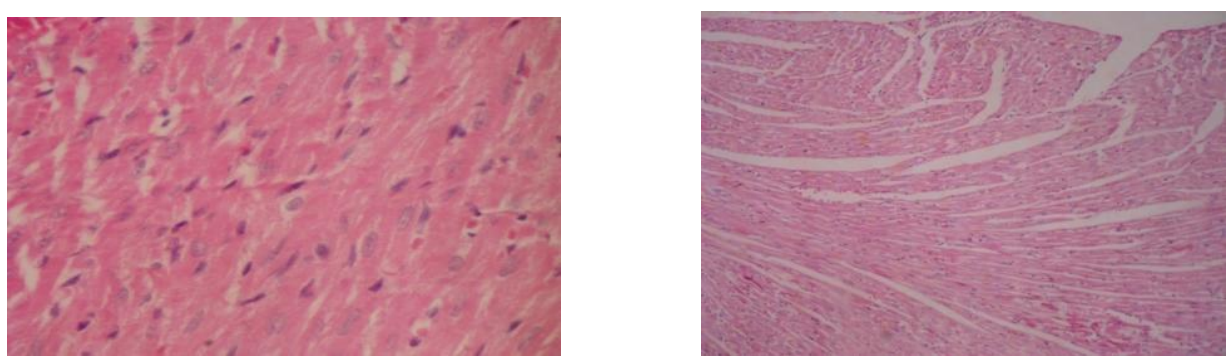

Plates 5 and 6: Photomicrograph of the heart of rats fed the control and Jatropha curcas seed oil-based diet for four weeks ( $H$ and $E \times 400$ ). There was no visible change in the architecture of the heart of animals fed the test diet compared to the control diet.
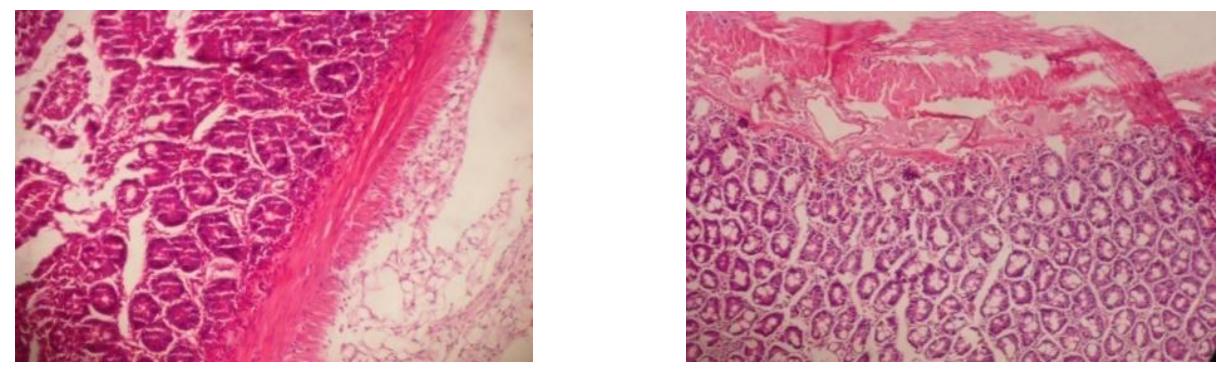

Plates 7 and 8: Photomicrograph of the small intestine of rats fed the control and Jatropha curcas seed oil-based diet for four weeks ( $H$ and $E \times 400$ ). There was no visible change in the architecture of the small intestine of animals fed the test diet compared to the control diet.

and food rejection as reported by (Makkar et al., 1998).

The digestibility of feedstuff is the major determinant of the quality of the feed. Lipid digestibility of Jatropha curcas seed oilbased diet is so low which corresponds to the phorbol esters present in it and thereby render the animals avoiding it. This might also be the reason for a higher percentage mortality in the Jatropha curcas seed oil fed group.

Hematological data were used as an indication of the health status of the experimental animals. Packed cell volume (PCV) measures the $\%$ of red blood cells in a given volume of whole blood. Values of the PCV and concentration of hemoglobin reported in this study shows no significant difference between the control and the test group. This signifies that the oxygen carrying component of the red blood cell (i.e. hemoglobin) is not altered and that ingestion of Jatropha curcas seed oil cannot induce anaemia (which is the reduction in the haemoglobin concentration of the blood (Moss, 1999). White blood cell count is the count of the actual number of white blood cells per volume of blood. It was observed that there were no significant difference in the total white blood cell count between the control and the test group. Furthermore, the differential looks at the different white blood cells present and the result shows no significant differences in the lymphocytes, monocytes and eosinophils. The reduction observed in neutrophils of animals fed on test diet could be due to the antinutrients present in the oil. This work is comparable to the work on effect of various levels of dietary Jatropha curcas seed meal on rabbits infested by the adult ticks of Hyalomma marginatum, marginatum $I$. animals performance, anti-tick feeding and haemogram (Sobhy et al., 2010). This indicates that ingestion of Jatropha curcas seed oil does not reduce the animal's immunologic response against infections and diseases but on a long run could reduce immnunity if complete detoxification is not achieved. In conclusion, complete detoxification will be necessary for Jatropha curcas seed oil before been incorporated into animal diet. 


\section{References:}

Achten, W., Mathijs, E., Verchot, L., Singh, V. P. and Muys, B. (2007). Bio-diesel from Jatropha: the life-cycle perspective. Expert seminar on Jatropha curcas $L$. Agronomy and genetics. 26-28 March 2007, Wageningen, the Netherlands, Published by FACT Foundation.

Achten, W. M. J., Verchot, L., Franken, Y. J., Mathijs, E., Singh, V. P., Aerts, B. and Muys, R. (2008). Jatropha bio-diesel production and use, Biomass Bioenerg. 32, 2008, 1063-1084.

Augustus, G. D. P. S., Jayabalan, M. and Seiler, G. J. (2002). Evaluation and bioinduction of energy components of Jatropha curcas. Biomass Bioenergy; 23(3):161-4.

Belewu, M. A., Yahya, A. A. and Adeyina, A. O. (2008). Study on the haematological parameters of goats fed Aspergillus treated and untreated shea-butter cake. Research Journal Animal Science 2 (5): 154-156.

Butler, L. G. (1989). Effects of condensed tannins on animal nutrition. In: Chemistry and significance of condensed tannins. Hemingway and Karchesy. Eds. Plenum Press, New York, 391-402.

Butler, L. G. (1992). Antinutrient effect of condensed and hydrolysable tannins. Basic Life Science 59, 693-698.

Carraretto, C., Macor, A., Mirandola, A., Stoppato, A. and Tonon, S. (2004). Biodiesel as alternative fuel: Experimental analysis and energetic evaluation, Energy, 29, 21952211.

Dacie, S. V and Lewis, S. M. C. (2006). Practical hematology, tenth edition. $\mathrm{Pg}$ 25-57.

Drury, R. A. B. and Wellington, E. A. (1973). Tissue histology. In: Carleton's Histological Technique 4th ed., Pg 120. Oxford University Press, New York.

Gübitz, G. M., Mittelbach, M., and Trabi, M. (1999). Exploitation of the tropical oil seed plant Jatropha curcas L. Bior Tech; 67:7382.
Janick, J., and Robert E. P. (2008). The encyclopedia of food and nut. CABI. pp. 371-372.

Makkar, H. P. S., Becker, K. and Schmook, B. (1998). Edible provenances of Jatropha curcas from Quintana Roo state of Mexico and effect of roasting on antinutrient and toxic factors in seeds. Plant Foods Human Nutrition 52, 3136.

Moss, P. P. (1999). Blood banking: Concepts and Applications. W.B. Saunders Co. Philadelphia pp: $12-34$.

Muhammad, N. O. and Oloyede, O. B. (2004). Assessment of Biological Value of Terminalia catappa seed meal-based diet in rats. Biokemistri 16, 49-55.

Muhammad, N. O., Oloyede, O. B., Owoyele, B. V. and Olajide, J. E. (2004). Deleterious effects of defatted Terminalia catappa seed meal-based diet on haematological and urinary parameters of albino rats. NISEB Journal 4, 51-57.

Muhammad, N. O. and Oloyede, O. B. (2010). Effects of Aspergillus niger-fermented Terminalia catappa seed meal-based diet on selected enzymes of some tissues of broiler chicks. Food and Chemical Toxicology (In Press).

Sobhy, A-S., Soad, M. N., Hashem, H. A. and Salwa, M. H. (2010). Effect of various levels of dietary Jatropha curcas seed meal on rabbits infested by the adult ticks of Hyalomma marginatum marginatum I. Animal performance, anti-tick feeding and haemogram. Egypt Trop Anim Health Prod (2011) 43:347-357.

Vaitilingom, G. and Leinnard, A. (1997). Biofuels and industrial product from Jatropha curcas, In:G.M. Gubitz, M. Mittlebach and M. Trabi (Eds). Biofuels and industrial products from Jatropha curcas. Dbv-Verlag fur die Technische Unversitat Graz, Graz, Austria, pp.98-109. 